\title{
PENGARUH MODEL PEMBELAJARAN PROBLEM BASED LEARNING BERBANTUAN MEDIA CROCODILE PHYSICS TERHADAP PENGUASAAN KONSEP FISIKA MATERI USAHA DAN ENERGI DI SMAN 1 BENGKULU TENGAH
}

\author{
Hesti Juliani*, Iwan Setiawan, Desy Hanisa Putri \\ Program Studi S1 Pendidikan Fisika Universitas Bengkulu \\ Jalan WR. Supratman, Kandang Limun Bengkulu \\ e-mail : hestijuliani123@gmail.com
}

\begin{tabular}{c|c|c|c}
\hline Diterima 19 Juli 2020 & Direvisi 31 Juli 2021 & Disetujui 20 Agustus 2021 & Dipublikasikan 28 Agustus 2021 \\
\hline \multicolumn{4}{c}{ https://doi.org/10.33369/jkf.4.2.85-92 } \\
\hline
\end{tabular}

\begin{abstract}
ABSTRAK
Penelitian ini bertujuan untuk mengetahui apakah terdapat pengaruh yang signifikan dari penerapan model pembelajaran problem based learning berbantuan media crocodile physics terhadap penguasaan konsep fisika materi usaha dan energi di SMAN 1 Bengkulu Tengah. Jenis penelitian yang digunakan adalah penelitian Quasi Experiment. Sampel penelitian diambil menggunakan teknik purposive sampling yang sebelumnya telah diuji normalitas dan homogenitasnya sehingga ditetapkan siswa kelas X IPA 3 sebagai kelas uji coba (eksperimen) dan kelas X IPA 1 sebagai kelas kelas kontrol. Teknik pengumpulan data menggunakan observasi, wawancara, dan dokumentasi untuk mendapatkan populasi dan sampel serta tes untuk tingkat penguasaan konsep fisika. Analisis data diuji menggunakan analisis korelasi product moment. Uji prasyarat analisis data berupa uji normalitas dan homogenitas. Berdasarkan analisa data diperoleh kesimpulan bahwa terdapat pengaruh positif yang besar dari penerapan model pembelajaran Problem Based Learning berbantuan media Crocodile Physics terhadap penguasaan konsep fisika materi usaha dan energi Di SMAN 1 Bengkulu Tengah. Hal ini ditunjukkan dari hasil uji t dimana nilai $t_{\text {hitung }}$ lebih besar dari $t_{\text {tabel }}(7,77$ $>1,99$ untuk $\alpha=5 \%)$ dan (7,77 > 1,66 untuk $\alpha=10 \%)$ serta uji effec size sebesar 1,94 yang masuk dalam kriteria besar. Jadi dapat disimpulkan bahwa model pembelajaran Problem Based Learning berbantuan media Crocodile Physics memberikan pengaruh yang besar terhadap kemampuan penguasaan konsep fisika siswa.
\end{abstract}

Kata kunci : Besar pengaruh, penguasaan konsep, problem based learning, crocodile physics

\begin{abstract}
ABSTRAK
This research aimed to determine whether there was a significant the influence of the application of the problem based learning model assisted by crocodile physics media on the mastery of physics concepts on work and energy topic in SMAN 1 Bengkulu Tengah. This type of research was a Quasi Experiment research. The research sample was taken by purposive sampling technique that had previously been tested for normality and homogeneity so that the students of Class X Science 3 were assigned as the experimental class and Class X Science 1 as the control class. Data collection techniques was used are observation, interviews, and documentation to get populations and samples as well as tests for the level of mastery of physical concepts. Data analysis was tested using product moment correlation analysis. The prerequisite test for data analysis is a test for normality and homogeneity. Based on the data analysis, it can be concluded that there is a large positive influence from the application of the Problem Based Learning model with the help of Crocodile Physics media on the mastery of the concepts of work and energy topic in SMAN 1 Bengkulu Tengah. This is shown from the results of the $t$ test in which the $t$ value is greater than $t$ table $(7.77>1.99$ for $\alpha=5 \%)$ and (7.77> 1.66 for $\alpha=10 \%)$ and the effect size test is 1,94 which is included in the big criteria. So it can be concluded that the Problem Based Learning model which is assisted by Crocodile Physics media has a great influence on the ability to master the concepts of student physics.
\end{abstract}

Keywords : Great influence, Mastery of Concepts, problem based learning, Crocodile Physics

\section{PENDAHULUAN}

Ilmu fisika merupakan ilmu yang mempelajari mengenai fenomena atau gejala alam. Dalam proses pembelajaran fisika dilengkapi dengan praktikum yang bersifat ilmiah dengan harapan dapat 
mempermudah siswa dalam mengkonstuksi dan memperoleh pengetahuan. Sehubungan dengan hal itu, fisika merupakan mata pelajaran sains yang diharapkan mampu meningkatkan kemampuan generik fisika dan penguasaan konsep siswa melalui pembelajaran (1).

Pada hakikatnya kegiatan belajar- mengajar akan efektif jika guru dapat mengubah kemampuan dan persepsi siswa dari yang sulit mempelajari sesuatu menjadi mudah mempelajarinya. Lebih jauh dijelaskan bahwa proses belajar-mengajar yang efektif ditentukan oleh pemilihan dan penggunaan motode pembelajaran untuk dapat memaksimalkan pembelajaran (2).

Secara psikologis media pembelajaran berpengaruh besar terhadap hasil belajar siswa. Faktorfaktor yang mempengaruhi belajar salah satunya adalah faktor-faktor non-sosial dalam belajar. Contohnya suhu, cuaca, waktu, tempat, media yang digunakan (alat tulis, buku-buku, alat-alat peraga, dan sebagainya yang biasa kita sebut alat-alat pelajaran) (3). Selanjutnya Bloom mengemukakan penguasaan konsep merupakan suatu kemampuan menangkap pengertianpengertian seperti mampu mengungkapkan suatu materi yang disajikan ke dalam bentuk yang lebih dipahami, mampu memberikan interpretasi dan mampu mengaplikasikannya (4).

SMA Negeri 1 Bengkulu Tengah salah satu sekolah yang sudah menerapkan kurikulum 2013, model pembelajaran yang kerap dilaksanakan adalah model pembelajaran langsung (Direct Instruction). Berdasarkan hasil wawancara dan observasi awal yang dilakukan, didapatkan hasil bahwa hasil ujian semester fisika siswa masih sangat rendah dalam artian tidak mencapat nilai KKM sebesar 76. Hal ini disebabkan karena kemampuan siswa dalam menguasai konsep masih sangat rendah. Oleh karena itu, dibutuhkan suatu model pembelajaran dan media pembelajaran yang mampu meningkatkan kemampuan penguasan konsep tersebut.

Salah satu model pembelajaran yang dapat mengembangkan kemampuan penguasaan konsep adalah model Problem Based Learning (PBL). Problem Based Learning, yaitu suatu model pembelajaran yang menggunakan masalah dunia nyata sebagai suatu konteks bagi siswa untuk belajar melalui berpikir kritis dan keterampilan pemecahan masalah dalam rangka memperoleh pengetahuan dan konsep yang esensi dari materi pelajaran (5). Problem Based Learning (PBL) merupakan salah satu model pembelajaran yang menuntut aktivitas mental siswa untuk memahami suatu konsep pembelajaran melalui situasi dan masalah yang disajikan pada awal pembelajaran dengan tujuan untuk melatih siswa menyelesaikan masalah dengan menggunakan pendekatan pemecahan masalah (6). Berikut ini Tabel langkah-langkah model PBL.

Tabel 1. Langkah-langkah model pembelajaran PBL

Tahap

Kegiatan Guru

Tahap 1: Orientasi siswa kepada masalah

Tahap 2: Mengorganisasikan siswa untuk belajar

Tahap 3: Membantu penyelidikan mandiri dan Kelompok

Tahap 4: Mengembangkan dan menyajikan hasil karya serta memamerkannya

Tahap 5: Menganalisis dan mengevaluasi proses pemecahan masalah Guru menginformasikan tujuan-tujuan pembelajaran,
mendeskripsikan kebutuhan-kebutuhan logistik penting, dan memotivasi siswa agar terlibat dalam kegiatan pemecahan masalah yang mereka pilih sendiri.
Guru membantu siswa menentukan dan mengatur tugas-tugas belajar yang berhubungan dengan masalah itu.
Guru mendorong siswa mengumpulkan informasi yang sesuai, melaksanakan eksperimen, mencari penjelasan, dan solusi.
Guru membantu siswa dalam merencanakan dan menyiapkan hasil karya yang sesuai seperti laporan, rekaman video, dan model, serta membantu mereka berbagi karya mereka.
Guru membantu siswa melakukan refleksi atas penyelidikan dan proses-proses yang mereka gunakan.

Tabel di atas menunjukkan bahwa dalam model PBL ada lima langkah ilmiah yang harus diimplementasi dalam proses pembelajaran agar siswa dapat menguasai konsep dari materi fisika.

Media pembelajaran yang digunakan berupa media virtual lab Crocodile physic. Crocodile physic merupakan program yang dikembangkan oleh Crocodile company, yang didalam program tersebut menyediakan mini laboratorium untuk mata pelajaran fisika pada pendidikan menengah yang didalam program tersebut berupa dinamika, kinetika, energi, gelombang, optik, dan listrik (7). Berikut ini gambar tampilan awal dari software crocodile physics. 


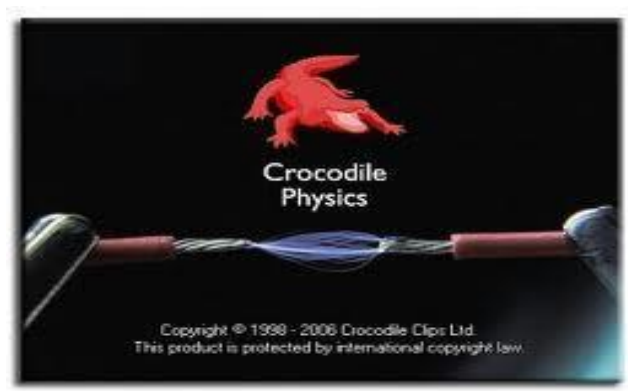

Gambar 1. Tampilan awal software crocodile physics.

Penelitian sebelumnya sudah ada yang berjudul "Penerapan Model Pembelajaran Problem Based Learning (PBL) dengan Media Audio Visual pada Materi Ikatan Kimia terhadap Penguasaan Konsep dan Berpikir Kritis Peserta Didik SMA Negeri 1 Panga" dan penelitian yang berjudul "Penerapan Program Crocodile Physic sebagai Media Pembelajaran dalam Upaya Meningkatkan Pemahaman Konsep Fisika Siswa". Perbedaan dari penelitian tersebut dengan penelitian ini adalah pada penggabungan antara model PBL dan media crocodile physics, serta pada materi yang diajarkan yaitu materi Usaha dan Energi. Penelitian model PBL menggunakan media crocodile physics belum pernah dilakukan di SMA, oleh karena itu dilakukan penelitian eksprimen menggunakan model pembelajaran PBL berbantuan media crocodile physics pada Materi Usaha dan Energi di SMAN 1 Bengkulu Tengah.

Berdasarkan uraian tersebut dirumuskan masalah sebagai berikut: 1). Bagaimana penerapan model PBL berbasis media crocodile physics dalam meningkatkan penguasaan konsep fisika siswa materi Usaha dan Energi di SMAN 1 Bengkulu Tengah? 2). Bagaimana pengaruh penerapan model pembelajaran PBL berbantuan media crocodile physics terhadap penguasaan konsep fisika siswa materi Usaha dan Energi di SMAN 1 Bengkulu Tengah?

\section{METODE PENELITIAN}

Jenis penelitian yang digunakan dalam penelitian ini adalah penelitian eksperimen. Sedangkan desain penelitian yang digunakan yaitu Quasi Eksperimental Design yang digunakan untuk membandingkan pemahaman konsep antara dua kelas yaitu kelas eksperimen dan kelas kontrol. Penelitian ini dilaksanakan dikelas X SMAN 1 Bengkulu Tengah yang berada di Desa Kembang Seri kec.Talang Empat dan dilaksanakan pada Tanggal 16- 24 Maret 2020 Tahun ajaran 2020/2021.

Pengambilan sampel dilakukan dengan purposive sampling. Purposive sampling adalah teknik penentuan sampel dengan pertimbangan tertentu (8). Pengambilan sampel dilakukan dengan mengambil 2 kelas dari 4 kelas X IPA yang ditentukan oleh pertimbangan guru fisika SMA Negeri 1 Bengkulu Tengah. Guru mempertimbangkan kelas yang diteliti berdasarkan nilai ulangan harian siswa, selanjutnya diuji normalitas dan homogenitas variansnya. Kelas X IPA 3 sebagai kelas eksperimen dengan menggunakan model pembelajaran Problem Based Learning dan kelas X IPA 1 sebagai kelas kontrol dengan menggunakan model Direct Instruction.

Teknik pengumpulan data dengan melakukan 2 tes yaitu pretest dan posttest. Dengan soal pretest dan soal posttest adalah soal yang sama dan berbentuk essay. Tes penguasaan konsep diberikan dikelas eksperimen dan kelas kontrol. Pengaruh model pembelajaran Problem Based Learning terhadap penguasaan konsep dianalisis menggunakan uji t terhadap rata-rata nilai Posttest kedua kelas. Dalam penelitian ini analisis parametrik yang digunakan untuk menentukan pengaruh pembelajaran Problem Solving Fisika terhadap penguasaan konsep adalah uji T karena data ratarata Posttest penguasaan konsep yang diperoleh berdistribusi normal dan homogen. Rumus t-test yang digunakan yaitu uji t polled varian dengan derajat kebebasan $(d k)=\mathrm{n}_{1}+\mathrm{n}_{2}-2$ (9), dengan persamaan sebagai berikut:

$$
t=\frac{\overline{X_{1}}-\overline{X_{2}}}{\sqrt{\frac{s_{1}^{2}}{n_{1}}+\frac{s_{2}^{2}}{n_{2}}}}
$$


$\mathrm{t}$ adalah skor $\mathrm{t}$ hitung, $\bar{x}_{1}$ adalah skor rata-rata pretest dan postest pemahaman konsep kelas eksperimen, $\bar{x}_{2}$ adalah skor rata-rata pretest dan postest pemahaman konsep kelas kontrol, $n_{1}$ adalah jumlah sampel kelas eksperimen, $n_{2}$ adalah jumlah sampel kelas kontrol, $\mathrm{s}_{1}^{2}$ adalah varian kelas eksperimen, dan $\mathrm{s}_{2}^{2}$ adalah varian kelas kontrol. Dasar pengambilan keputusan adalah jika harga $t_{\text {hitung }}>t_{\text {tabel }}$ pada taraf signifikansi $(\alpha)=5 \%$ dan $(\alpha)=10 \%$ dan derajat kebebasan $(\mathrm{dk})=\mathrm{n}_{1}+\mathrm{n}_{2}$ -2, maka Ho ditolak dan Ha diterima. Berdasarkan analisis data yang diperoleh dapat diketahui apakah hipotesis yang diajukan dalam penelitian ini diterima atau ditolak. Setelah diperoleh bahwa model pembelajaran Problem Based Learning memberikan pengaruh terhadap penguasaan konsep, maka selanjutnya dilakukan uji effect size untuk mengetahui besar pengaruh model PBL berbantuan media crocodile physics terhadap penguasaan konsep. Effect size adalah ukuran mengenai besarnya pengaruh suatu variabel terhadap variabel lainnya. Effect size memberikan informasi tentang ukuran (size) dari akibat suatu perlakuan eksperimen (effect) yang sangat penting karena memberikan ukuran seberapa besar pengaruh perlakuan terhadap suatu variabel dalam eksperimen (10). Perhitungan effect size untuk mengukur besar pengaruh model pembelajaran Problem Based Learning berbantuan media crocodile physics terhadap penguasaan konsep dilakukan dengan menggunakan rumus Cohen's $d$.

$$
d=\frac{\overline{x_{E}}-\overline{x_{C}}}{S_{\text {pooled }}}
$$

$\mathrm{d}$ adalah effect size, $\overline{x_{E}}$ adalah rata-rata posttest kelas eksperimen, $\overline{x_{C}}$ adalah rata-rata posttest kelas kontrol, dan $\mathrm{S}_{\text {Pooled }}$ adalah standar deviasi gabungan. Standar deviasi gabungan ditentukan menggunakan persamaan (3).

$$
S_{\text {pooled }}=\sqrt{\frac{\left(n_{E}-1\right) \mathrm{S}_{E}^{2}+\left(\mathrm{n}_{C}-1\right) \mathrm{S}_{C}^{2}}{n_{E}+n_{C}-2}}
$$

$n_{E}$ adalah jumlah siswa kelas eksperimen, $n_{C}$ adalah jumlah siswa kelas kontrol $S_{E}^{2}$ adalah varians kelas eksperimen, $S_{C}^{2}$ adalah varians kelas kontrol. Hasil perhitungan effect size diinterpretasikan dengan menggunakan klasifikasi Cohen (11).

Tabel 2. Klasifikasi Cohen (effect size)

\begin{tabular}{cc}
\hline Besar $\boldsymbol{d}$ & Interpretasi \\
\hline $0,8 \leq d \leq 2,0$ & Besar \\
$0,5 \leq d<0,8$ & Sedang \\
$0,2 \leq d<0,5$ & Kecil \\
\hline
\end{tabular}

Tabel 2 diatas menunjukkan bahwa ada tiga klasifikasi dari hasil perhitungan effect size. Yang pertama termasuk klasifikasi ukuran pengaruh yang kecil jika hasil perhitungan sebesar 0,2 sampai 0,5 . Sedangkan ukuran pengaruh sedang dengan nilai sebesar 0,5 sampai 0,8 . Ukuran pengaruh besar nilai nya sebear 0,8 sampai 2,0 .

\section{HASIL DAN PEMBAHASAN}

\subsection{Data Hasil Tes Kelas Eksperimen dan Kelas Kontrol}

Berdasarkan hasil pretest dan posttest pada pertemuan pertama tersebut, maka didapatkan nilai rata-rata pretest dan posttest kelas eksperimen adalah 19,313 dan 76,156, nilai pretest tertinggi 35 dan terrendah 10, nilai postest tertinggi 85 dan terendah 60, serta standar deviasi pretes 5,29 dan postes 8,4 . Sedangkan pada kelas kontrol didapatkan nilai rata-rata pretest dan posttest kelas kontrol adalah 17,16 dan 57,00, nilai pretest tertinggi 40 dan terrendah 8 , nilai postest tertinggi 70 dan terendah 30 , serta standar deviasi pretes 6,78 dan postes 11,13 . Grafik perbedaan nilai rata-rata pretest dan posttest kedua kelas tersebut dapat dilihat pada gambar 1. 


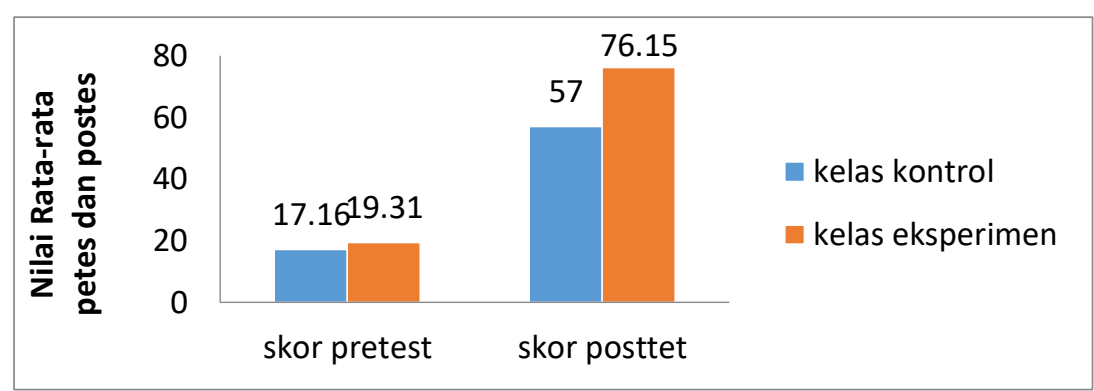

Gambar 2. Rata-rata tes penguasaan konsep pretest dan posttest kelas eksperimen dan kelas kontrol Dari grafik diatas dapat dilihat bahwa nilai pretest kedua kelas berada pada nilai yang hampir sama dan ditunjukkan pada tinggi grafiknya yang hampir sama. Sedangkan pada nilai posttest kedua kelas terlihat dari tinggi grafik yang perbedaannya cukup jauh. Grafik batang kelas eksperimen lebih tinggi dari kelas kontrol. Hal ini menunjukkan bahwa pada kelas eksperimen terjadi peningkatan menguasai konsep yang cukup signifikan dibandingkan kelas kontrol.

\subsection{Uji persyaratan Hipotesis}

Untuk mengetahui data hasil penelitian berdistribusi normal atau tidak. Maka dilakukan uji normalitas nilai rata-rata pretest dan posttest pemahaman konsep. Hasil Perhitungan uji normalitas Pemahaman Konsep dapat dilihat dalam Tabel 1.

Tabel 3. Hasil Perhitungan Uji Normalitas Data Sampel

\begin{tabular}{ccccc}
\hline Kelas & Data & $\begin{array}{c}\mathbf{L}_{\text {hitung }} \\
\left(\mathbf{L}_{\mathbf{0}}\right)\end{array}$ & $\begin{array}{c}\mathbf{L}_{\text {tabel }}\left(\mathbf{L}_{\mathbf{1}}\right) \mathbf{n}=\mathbf{3 2} \\
(\boldsymbol{\alpha})=\mathbf{0 , 0 5 .}\end{array}$ & Keterangan \\
\hline \multirow{2}{*}{ Eksperimen } & Rata-rata Pretest & 0,079 & 0,157 & Normal \\
& Rata-rata Posttest & 0,146 & 0,157 & Normal \\
\multirow{3}{*}{ Kontrol } & Rata-rata Pretest & 0,107 & 0,157 & Normal \\
& Rata-rata Posttest & 0,150 & 0,157 & Normal \\
\hline
\end{tabular}

Dari tabel 3 di atas dapat kita lihat bahwa data pretes dan postes pada kelas eksperimen dan kelas kontrol menunjukkan hasil yang normal. Hal ini karena nilai Lhitung pretes maupun postes lebih kecil daripada Ltabel seperti yang tertera pada tabel.

Selanjutnya untuk menentukan apakah sampel berasal dari varians yang homogen, dilakukan uji homogenitas nilai rata-rata Pretest dan Posttest pemahaman konsep. Hasil Perhitungan uji homogenitas Pemahaman Konsep dapat dilihat dalam Tabel 2.

Tabel 4. Hasil perhitungan Uji Homogenitas Varians

\begin{tabular}{ccccc}
\hline Kelas & $\begin{array}{c}\text { Jumlah } \\
\text { sample(n) }\end{array}$ & Df & $\begin{array}{c}\text { Varians } \\
\text { pretes }\end{array}$ & $\begin{array}{c}\text { Varians } \\
\text { postes }\end{array}$ \\
\hline Eksperimen & 32 & 31 & 28,028 & 70,523 \\
Kontrol & 32 & 31 & 45,943 & 123,935 \\
Fhitung & & 1,639 & 1,757 \\
Ftabel pada 0,05 & \multicolumn{2}{c}{1,822} \\
Syarat & Fhitung $<$ Ftabel = Homogen \\
Status Varians & \multicolumn{3}{c}{ Homogen Homogen } \\
\hline
\end{tabular}

Berdasarkana tabel diatas didapatkan uji homogenitas varians pretes kedua kelas menunjukkan hasil yang yang homogen. Hal ini karena nilai F hitungnya lebih kecil dari Ftabel $(1,639<1,822)$. Selain varians postes kedua kelas juga menunjukkan hasil yang yang homogen. Hal ini karena nilai $\mathrm{F}$ hitungnya lebih kecil dari Ftabel itu $(1,757<1,822)$.

\subsection{Uji Hipotesis dan Effec size}

Setelah didapatkan bahwa data berdistribusi normal dan homogen, maka dilakukan uji t. Berikut adalah hasil uji T nilai Pretest dan Posttest pemahaman konsep masing-masing kelas dapat dilihat pada Tabel 3. 
Tabel 5. Hasil Uji T Pretest dan Posttest Pemahaman Konsep

\begin{tabular}{ccccccccc}
\hline \multirow{2}{*}{ Hasil } & Kelas & N & $\begin{array}{c}\text { Rata- } \\
\text { rata }\end{array}$ & Varians & t & $\mathbf{5 \%}$ & $\mathbf{1 0 \%}$ & Kesimpulan \\
\hline Pretest & Eksperimen & 32 & 19,31 & 28,02 & 1,41 & 1,99 & 1,66 & Tidak berbeda \\
& Kontrol & 32 & 17,15 & 45,94 & 1,41 & 1,99 & 1,66 & signifikan \\
Posttest & Eksperimen & 32 & 76,15 & 70,52 & 7,77 & 1,99 & 1,66 & Berdeda \\
& Kontrol & 32 & 57,00 & 123,93 & 7,77 & 1,99 & 1,66 & signifikan
\end{tabular}

Berdasarkan tabel 5 terlihat bahwa hasil uji beda rata-rata Pretest kelas eksperimen dan kelas kontrol tidak berbeda secara signifikan. Hal ini menunjukkan bahwa pemahaman konsep sebelum diberi perlakuan (Pretest) tidak terdapat perbedaan sehingga dapat disimpulkan bahwa kedua kelas mempunyai kemampuan yang sama saat sebelum diberi perlakuan atau Pretest kedua kelas tidak terdapat perbedaan yang signifikan. Berdasarkan pemahaman konsep sebelum diberi perlakuan (Pretest) bahwa tidak terdapat perbedaan yang signifikan maka perlakuan pembelajaran dapat diberikan pada masing-masing kelas. Hasil uji t data Posttest menunjukkan bahwa besar $\mathrm{t}_{\text {hitung }}$ nilai posttest kelas eksperimen dan kelas kontrol lebih besar dari pada $\mathrm{t}_{\text {tabel }}$, yang artinya Ha diterima dan Ho ditolak. Hal ini menunjukkan bahwa kemampuan menguasai konsep siswa kelas eksperimen dan kelas kontrol terdapat perbedaan.

Dengan adanya perbedaan hasil belajar siswa kelas eksperimen dan kelas kontrol, maka dapat disimpulkan bahwa pembelajaran menggunakan model PBL berbantuan media Crocodie Physics memberikan pengaruh terhadap kemampuan penguasaan konsep fisika siswa. Perbedaan penguasaan konsep antara kelas eksperimen dan kelas kontrol dapat terjadi karena disebabkan oleh beberapa faktor. Salah satu faktor yang mempengaruhi penguasaan konsep siswa yaitu penggunaan model pembelajaran sehingga ketepatan memilih model pembelajaran diharapkan dapat meningkatkan hasil belajar siswa, terutama meningkatkan penguasaan konsep siswa. Salah satu alternatif model pembelajaran inovatif yang dikembangkan berlandaskan paradigma konstruktivistik yang dapat membantu siswa dalam membangun pengetahuannya yaitu model pembelajaran Problem Based Learning (12).

Selain itu, media pembelajaran juga sangat berpengaruh untuk meningkatkan penguasaan konsep siswa. Media pembelajaran adalah alat bantu berupa fisik maupun nonfisik yang sengaja digunakan sebagai alat perantara antara guru dan peserta didik dalam memahami materi pembelajaran agar lebih efektif dan efisien. Media berperan sangat penting di dunia pendidikan. Beberapa penelitian sebelumnya menunjukan bahwa ada pengaruh penggunaan media simulasi di dalam kelas (13).

Selanjutnya untuk mengukur seberapa besar pengaruh (effect size) yang diberikan oleh pembelajaran dengan menggunakan model PBL berbantuan media crocodile physics terhadap penguasaan konsep, perlu dilakukan uji lanjut menggunakan rumus Cohen's. Hasil perhitungan yang diperoleh menunjukkan bahwa pengaruh yang diberikan berada dalam kategori besar, yaitu sebesar 1,94 sehingga dapat dikatakan bahwa model pembelajaran PBL berbantuan media crocodile physics berpengaruh besar terhadap penguasaan konsep siswa.

Hasil ini sejalan dengan penelitian yang dilakukan oleh Rerung (2017), yang menunjukkan bahwa "pembelajaran dengan menggunakan model pembelajaran PBL dapat meningkatkan hasil belajar peserta didik" (14). Berdasarkan hasil penelitian oleh Anugraheni (2018) "ternyata model pembelajaran Problem Based Learning mampu meningkatkan kemampuan berpikir Siswa mulai dari yang terendah 2,87\% sampai yang tertinggi 33,56\% dengan rata-rata 12,73\%" (15). Selain itu penelitian oleh Muslim (2015) menyimpulkan bahwa "model pembelajaran Problem Based Learning secara signifikan dapat lebih meningkatkan penguasaan konsep dan keterampilan berpikir kritis siswa SMA" (16). Kemudian penelitian oleh Malik (2015) Hasil penelitian menunjukkan "terdapat peningkatan penguasaan konsep dengan $\mathrm{N}$-gain sebesar 0,33 dengan interpretasi sedang, rata-rata keterampilan proses mahasiswa sebesar 82,28 dengan interpretasi baik sekali dan hubungan antara penguasaan konsep mahasiswa dan keterampilan proses sainsnya $\left(\mathrm{r}_{\mathrm{xy}}\right)$ sebesar 0,042 dengan interpretasi sangat rendah sehingga diabaikan. Dengan demikian dapat disimpulkan 
bahwa model pembelajaran problem based instruction dapat meningkatkan penguasaan konsep dan keterampilan proses sains mahasiswa pada mata kuliah Fisika Dasar" (17).

Kemudian penelitian yang mendukung media crocodile physics diantaranya : penelitian yang dilakukan oleh Gumrowi (2020), diperoleh bahwa "simulasi Crocodile physics pada model Think- Pair-Share dapat meningkatkan hasil belajar materi gelombang pada setiap siklusnya' (18). Selain itu penelitian Triratna Kereh (2020) menunjukkan bahwa "setelah proses pembelajaran menggunakan software Crocodile Physics 6.0.5, hasil belajar peserta didik menjadi lebih baik. Hal ini terlihat pada hasil rata-rata skor pencapaian yang diperoleh peserta didik pada aspek kognitif, afektif, psikomotor berturut-turut adalah 85,6; 86,9; dan 86,7. Ini berarti hasil belajar kelompok peserta didik tersebut dalam ketiga aspek ada pada kualifikasi baik. Rata-rata skor pencapaian tes formatif mereka juga baik $(86,5)$. Selain itu, nilai uji $n$-gain rata-rata diperoleh 0,8 yaitu pada kategori tinggi" (19).

Selanjutnya penelitian oleh Gumrowi (2016) dari hasil analisis diperoleh bahwa "strategi pembelajaran kooperatif tipe Team Assisted Individualization melalui simulasi crocodile physics dapat meningkatkan hasil belajar listrik dinamik. Rata-rata hasil belajar siswa meningkat pada siklus I dari 61,23 menjadi 68,13 pada siklus II atau meningkat $11,27 \%$, pada siklus III 72,63 atau meningkat $6,6 \% "(20)$.

\section{SIMPULAN DAN SARAN}

\subsection{Simpulan}

Berdasarkan hasil analisis data penelitian, dapat ditarik kesimpulan berdasarkan rumusan masalah yang ada, bahwa: 1).Telah diterapkan model PBL berbantuan crocodile physics, penerapan model ini dapat meningkatkan penguasaan konsep fisika siswa. Penerapan model PBL ini dilakukan dengan langkah-langkah ilmiah yang menuntut siswa untuk dapat menemukan sendiri jawaban dari masalah yang diberikan. Media crocodile physics digunakan sebagai alat praktium virtual yang membantu menunjukkan kepada siswa bagaimana konsep fisika dari materi usaha dan energi. Hal tersebut dapat terjadi karena didalam model PBL terdapat langkah-langkah ilmiah yang menuntut siswa untuk dapat menemukan sendiri jawaban dari masalah yang diberikan. Media crocodile physics digunakan sebagai alat praktium virtual yang membantu menunjukkan kepada siswa bagaimana konsep fisika dari materi usaha dan energi tersebut. 2).Terdapat pengaruh penerapan model Problem Base Learning (PBL) berbantuan media crocodile physics terhadap peningkatan penguasaan konsep fisika siswa. Peningkatan pengusaan konsep tersebut dilihat dari nilai rata-rata posttest kelas eksperimen yang lebih tinggi dibandingkan dengan kelas kontrol. Selain itu juga dilihat dari hasil uji t sebagai uji pengaruh dengan $t$ hitung sebesar 7,77 yang lebih besar dari t tabel yaitu 1,99 untuk $\alpha=0,05$ dan 1,66 untuk $\alpha=0,10$ yang artinya terdapat pengaruh. Besarnya pengaruh ditunjukkan dari hasil uji lanjut (effect size) sebesar $\mathrm{d}=1,94$ yang termasuk dalam kriteria besar yaitu $0,8 \leq d \leq 2,0$. Dapat dikatakan bahwa model pembelajaran PBL berbantuan media crocodile physics memberikan pengaruh yang besar terhadap penguasaan konsep fisika siswa materi Usaha dan Energi di SMAN 1 Bengkulu Tengah.

\subsection{Saran}

Adapun saran dari penelitian ini adalah: 1) Penelitian ini hanya dilakukan dengan satu kali pertemuan dikarenakan adanya wabah virus corona, oleh karena itu pada penelitian selanjutnya akan sangat baik jika jumlah pertemuannya dipebanyak. 2) Pada penelitian ini, waktu yang dibutuhkan dirasa masih kurang, oleh karena itu penelitian selanjutnya dapat dirancang kembali agar waktu yang digunakan lebih efisien.

\section{UCAPAN TERIMA KASIH}

Penulis mengucapkan terima kasih kepada dosen atas bimbingannya selama ini dan terima kasih, guru Pamong di SMAN 1 Kota Bengkulu, validator dari instrumen tes serta pihak-pihak lain yang telah membantu penulis menyelesaikan penelitian ini. 


\section{DAFTAR PUSTAKA}

1. Nainggolan P, Rohadi N, Risdianto E. Konsep Dalam Pembelajaran Guided Discovery Melalui Eksperimen Pada Alat-Alat Optik. J Kumparan Fis. 2019;2(3):193-200.

2. suyanto dan asep jihad. menjadi guru profesional strategi meningkatkan kualifikasi dan kualitas guru di era global. Jakarta: esensi erlangga group; 2013.

3. Suryabrata S. psikologi pendidikan. Jakarta: PT Raja Grafindo Persada; 2014.

4. Silaban B. Hubungan antara penguasaan konsep fisika dan kreativitas dengan kemampuan memecahkan masalah pada materi pokok listrik statis. J Penelit Bid Pendidik. 2014;20(1):65-75.

5. Syaribuddin S, Khaldun I, Musri M. Penerapan Model Pembelajaran Problem Based Learning (Pbl) Dengan Media Audio Visual Pada Materi Ikatan Kimia Terhadap Penguasaan Konsep Dan Berpikir Kritis Peserta Didik Sma Negeri 1 Panga. J Pendidik Sains Indones (Indonesian J Sci Educ. 2016;4(2):96-105.

6. Vol JP. Http://Efektor.Unpkediri.Ac.Id. 2015;1(3):214-20.

7. Peran A, Milenial G, Pendidikan M, Sains P, Optik P, Sma DI. Seminar Nasional Pendidikan Fisika 2018 Efektifitas Media Elektronik Crocodile Physics Dalam Seminar Nasional Pendidikan Fisika 2018. 2018;3(2):107-13.

8. Sugiyono. Metodologi Penelitian Pendidikan. Bandung: Alfabeta; 2010.

9. Widiyanto M. Statistika Terapan. Jakarta: PT Elex media Komputindo; 2013.

10. Thalheimer W, Cook S. How to calculate effect sizes from published research: A simplified methodology. 2002;1-9.

11. Cohen J. Statistical Power Analysis for the behavioral Sciences. New York: Lawrence Erlbaum Associates; 1988.

12. Dwi IM, Arif H, Sentot K. Pengaruh Strategi Problem Based Learning Berbasis Ict Terhadap Pemahaman Konsep Dan Kemampuan Pemecahan Masalah Fisika. J Pendidik Fis Indones. 2013;9(1):8-17.

13. Software P, Physics C, Glbb BB, Kereh CT, Ode W, Sapulette H. DALAM PEMBELAJARAN FISIKA MATERI GERAK LURUS. 2020;7(1):64-80.

14. Rerung,N.,Iriwi L.S. \& SWW. Penerapan Model Pembelajaran Problem Based Learning ( PBL ) untuk meningkatkan Hasil Belajar. J Ilm Pendidik Fis Al-BiruNi. 2017;06(April):4755.

15. Anugraheni I. Meta Analisis Model Pembelajaran Problem Based Learning dalam Meningkatkan Keterampilan Berpikir Kritis di Sekolah Dasar. Polygot [Internet]. 2018;14(1):9-18. Available from: http://dx.doi.org/10.19166/pji.v14i1.789

16. Muslim I, Halim A, Safitri R. Penerapan Model Pembelajaran Pbl Untuk Meningkatkan Penguasaan Konsep Dan Keterampilan Berpikir Kritis Siswa Pada Konsep Elastisitas Dan Hukum Hooke Di Sma Negeri Unggul Harapan Persada. J Pendidik Sains Indones (Indonesian J Sci Educ. 2015;3(2):35-50.

17. Malik A. Model Pembelajaran Problem Based Instruction untuk Meningkatkan Penguasaan Konsep dan Keterampilan Proses Sains Mahasiswa. J Penelit Pengemb Pendidik Fis. 2015;01(1):9-16.

18. Gumrowi A. Meningkatkan Hasil Belajar Materi Gelombang Menggunakan Simulasi Crocodile Physics Pada Model Think- Pair-Share. J Pendidik Fis. 2020;8(1):70.

19. Trinata kereh cicylia. penggunaan software crocodile physics 6.0.5 dalam pembelajaran fisika materi gerak lurus berubah beraturan. Inov dan pembelajaran Fis. 2020;07:16.

20. Gumrowi A. Meningkatkan Hasil Belajar Listrik Dinamik menggunakan Strategi Pembelajaran Team Assisted Individualization melalui Simulasi Crocodile Physics. J Ilm Pendidik Fis Al-Biruni. 2016;5(1):105. 